\title{
Constitutionalising EU Executive Rule-Making Procedures: A Research Agenda
}

\author{
Deirdre Curtin, Herwig Hofmann and Joana Mendes* \\ [published in European Law Journal, Vol. 19, No. 1, pp. 1-21 (2013)]
}

Abstract

The existence or non-existence of procedural rules for executive rule-making in the $E U$ is not merely a 'technical' question free of constitutional value choices. This article argues that constitutional principles such as transparency, openness and participatory democracy higblighted by the Treaty of Lisbon constitute decisive normative standards for the design of administrative procedures in the EU with a considerable impact on substantive outcomes. We apply such principles with regard to non-legislative rule making procedures in the EU, bighlight the salience of this discussion and argue that systematization of nonlegislative rule making procedures is needed in order to implement constitutional principles in a complex and plural environment.

\section{Introduction}

The EU is a legal system which, despite in historical terms being a young structure, has developed and transformed itself many times. One of the ways in which the European Union polity has evolved in recent years is in the nature and breadth of the tasks it performs as well as the range of actors who perform them. As might be expected, there is not always a smooth link between growth in policy making powers now touching almost every imaginable public policy objective, on the one hand, and the institutional structures, decision-making procedures and constitutional framing, on the other. This mismatch in part results from the fact that the evolution of the EU does not always take place according to a specific 'constitutional' blueprint. More than at the national level, the EU's institutional structures and decision-making procedures evolve beyond its formal constitutional frame, responding to the needs of the time and of specific policy areas, and re-shape its constitution accordingly. ${ }^{1}$ Yet, one stable characteristic of such developments is the integration of executive bodies of the EU and its Member States through diverse forms of procedural cooperation and actors such as networks of regulators, comitology, and agencies. ${ }^{2}$

\footnotetext{
* Deirdre Curtin and Joana Mendes, University of Amsterdam; Herwig C.H. Hofmann, University of Luxembourg. The general considerations and the contributions to this special edition build on work undertaken by the members of the working group on 'rule-making', of the Research Network on EU Administrative Law - ReNEUAL (http://www.reneual.eu) and were presented and discussed at conferences and workshops in Amsterdam and Luxembourg in 2011.

${ }^{1}$ See further, D. Curtin, Executive Power of the European Union (Oxford University Press, 2009).

2 On the structure of the EU administration, see, among others, E. Chiti, "The Administrative Implementations of European Union Law: a Taxonomy and its Implications', in H. Hofmann and A. Türk (eds), Legal Challenges in EU Administrative Law (Edward Elgar, 2009), at 9; J. Ziller, 'Exécution Centralisée et Execution Partagée: le Fédéralisme d'Exécution en Droit de l'Union Européenne', in J. Dutheil de la Rochère (ed), L'exécution du Droit de l'Union, Entre
} 
Progressively, a set of constitutional values emerged both as a result of case law of the Court of Justice as general principles of law and in (incremental) Treaty amendments. This now explicitly includes the principle of democracy. This principle has above all shaped the EU's institutional structures and EU lawmaking procedures. In this respect, the Treaty of Lisbon is the culmination of a process that has enabled the European Parliament to adopt "legislation" in many instances formally on equal footing with the Council. Arguably, rule-making outside of legislative procedures has been less influenced by the Union's constitutional provisions on democracy. Little is known about how these provisions are translated into executive rule-making, beyond the institutional controls envisaged in the specific cases of delegated and implementing regulation (Articles 290 and 291 TFEU). Nonetheless, our claim is that executive rule-making is subject to exactly the same constitutional values as EU lawmaking.

Rulemaking processes taking place outside the formal legislative procedures produce a variety of different regulatory acts that may serve various functions, such as agenda setting and policy definition (including, for example, resolutions of the European Council). Regulatory acts, in a broad sense, include legislative proposals and the respective preparatory acts, inter-institutional agreements, delegated and implementing acts, guidelines that define policy implementation. We use the term executive rulemaking in this article in a narrower and more specific sense as referring to the process of content definition of acts of general application that concretise policy or legislative options. By this we refer to processes that lead to the adoption of rules that potentially entail the solution, or the criteria of the solution, of more specific (individual) cases. As a result, the rules are likely to impact on the rights and legally protected interests of private persons and to shape acts of other public entities. Many such rules are enacted outside formalized procedures (e.g. information guidelines). The effects of rules may be legally relevant irrespective of their form, binding force and the procedures followed for their adoption. The Commission, agencies, comitology, standardization bodies, networks of national regulators and others issue guidelines and notices, designed to guide the implementation of EU law by Member States, EU bodies and individuals. Benchmarking and 'open methods of cooperation' that are primarily designed to coordinate policies in which the EU has only marginal competences are also part of the panorama of executive rulemaking, as are standards set by EU agencies or private or semi-private actors. These type of acts may obtain a type of quasi binding form, via legislative sanctioning or judicial interpretation. ${ }^{3}$

The vast array of actors, forms of acts and applicable procedures make it difficult to assess to what extent constitutional values infuse executive rulemaking, and, more precisely, how general principles are complied with across the legal system. This is all the

Mécanismes Communautaires et Droits Nationaux (Bruylant, 2009), at 111; E. Schmidt-Aßmann, 'Introduction: European Composite Administration and the Role of European Administrative Law', in O. Jansen and B. Schöndorf-Haubold (eds), The European Composite Administration (Intersentia, 2011), at 1.

${ }^{3}$ D. M. Trubek and L. Trubek, 'New Governance \& Legal Regulation: Complementarity, Rivalry and Transformation', (2007) 13 Columbia Journal of European Law 539. 
more so since the terrain is fragmented and rather sector-specific. Solutions to problems arising from the increase in powers, enlargement, 'crises' and other events were often crafted according to specific needs of single policy areas or developed creatively in order to address concrete problems resulting from the differing interests between EU institutions and Member States or resulting from inter-institutional conflict. These processes have tended to be predominantly result-oriented, rather than value-oriented.

In the context of this dynamic and 'living' constitutional environment and in view of the highly diversified set of actors involved in executive rule-making, the aim of this special edition is twofold. First, it aims to contribute to the understanding of the rules that guide rulemaking, or, in other words, the 'meta norms' that shape the procedures through which executive rules are produced. The individual contributions focus on the rules about how rules are made. These can either be legislative in nature - e.g. the comitology regulation, policy specific legislation such as the procedural rules on state aid, antidumping, banking supervision ${ }^{4}$ - or emerge from institutional practice (e.g. impact assessment guidelines) or judicial practice (eg general principles of law). Second, we defend the thesis that meta rules should be perceived as tools capable of infusing core constitutional principles into executive rulemaking. ${ }^{5}$ Our introduction to this special issue will substantiate the case for the constitutionalization of rulemaking. We argue that the moment has come to give effect to the constitutional promises now newly in place also at the level of executive rulemaking.

\section{Administrative procedures as constitutional law}

The existence or non-existence of procedural rules for executive rule-making in the EU is not merely a 'technical' question free of constitutional value choices. Procedures can have a decisive impact on substantive outcome. They provide a structure to the multiple contacts that an administrative entity establishes with other administrative entities, experts, interest groups, and persons concerned, in order to reach a decision. ${ }^{6}$ Procedures channel moreover the flow of information that decision-making requires and mitigate possible information asymmetries between relevant actors. ${ }^{7}$ Procedures accommodate possible conflicts that may emerge between competing interests, the pursuance of which is framed by legal and constitutional norms. They are techniques that allow for the

\footnotetext{
${ }^{4}$ Respectively, Regulation (EC) 182/2011 of 16 February 2011 of the European Parliament and of the Council laying down the rules and general principles concerning mechanisms for control by Member States of the Commission's exercise of implementing powers, OJ 2011 L 55/13; Council Regulation 659/1999 of 22 March 1999laying down detailed rules for the application of Article 93 of the EC Treaty, OJ 1999 L 83/1; Council Regulation (EC) No $1225 / 2009$ on protection against dumped imports from countries not members of the European Community, OJ 2009 L 343/51; Regulation (EU) 1095/2010 of the European Parliament and of the Council of 24 November 2010 establishing a European Supervisory Authority (European Securities and Markets Authority), amending Decision No 716/2009/EC and repealing Commission Decision 2009/77/EC, OJ 2010 L 331/84.

5 On founding principles, see A. von Bogdandy, 'Founding Principles', in A. von Bogdandy and J. Bast (eds), Principles of European Constitutional Law (Hart Publishing, 2010), at 11, 21-23.

${ }^{6}$ E. Schmidt-Aßmann, La Teoría General del Derecho Administrativo Como Sistema (Marcial Pons, 2003), at 358.

7 ibid and M. McCubbins et al., 'Administrative Procedures as Instruments of Political Control', (1987) 3 Journal of Law, Economics, and Organization 243, at 246 and 255 (referring to the US context).
} 
balancing and articulation of interests that lie at the core of the administrative function and can concretise constitutional rights. ${ }^{8}$

Information and balancing of competing interests are crucial to the choice between different alternatives that make specific the legislative goals in particular, but also, indirectly, constitutional norms. ' In other words, "by structuring the rules of the game [...], administrative procedures sequence agency activity, regulate its information collection and dissemination, limit its available choices, and define its strategic advantages". ${ }^{10}$ As such they are also an instrument of political control and affect the range of decisions available to the decision-maker. ${ }^{11}$ Arguably proceduralisation enhances the rationality of decision-making and potentially enhances equality of access. In this sense, "the essence of the decision lies more in its preparation ... than in the decision itself". "The preparatory stages of decision-making, from the moment of its being put on the agenda to the moment of its formal adoption, are precisely the stages that are newly influenced by core constitutional principles that may well be changing the rules of the game in a manner that is not yet fully visible or operationalised.

But formal (administrative) procedures do more than influence in terms of input the content of decisions, they are also an essential aspect of the legal architecture within which the executive operates. Moreover, if we understand administration as being part of public law and therefore bound by constitutional norms and values, rule-making procedures with all their structural and institutional complexity should be subject to analysis as to whether they contribute to realising constitutional principles and values of the Union. In this sense, executive rulemaking procedures should fulfil and concretise the constitutional values and principles that shape the EU's constitutional form and nature, and, therefore, both ground and frame the legitimate exercise of public authority. ${ }^{13}$ On this basis, one may argue that the values and legal principles pursued by the choices made by executive rule-making procedures - and a possible codification or non-codification thereof - are constitutional in nature. In that sense, the law of administrative procedures is the continuation of constitutional law by other means or, with other words, the concretisation of constitutional law. ${ }^{14}$

Arguably, the Treaty of Lisbon buttresses an overtly constitutional approach to this subject in a variety of ways. First, it distinguishes and indeed names a legislative function and a non-legislative function. In so doing it explicitly lays down the contours of

\footnotetext{
${ }^{8}$ E. Schmidt-Aßmann (n 6 supra), at 163. The administrative procedure is a 'surrogate of political process' (R. Stewart, 'The Reformation of American Administrative Law', (1975) 88 Harvard Law Review 1669. On different conceptions on the function of administrative procedures, see V. Pereira da Silva, Em busca do Acto Administrativo Perdido (Livraria Almedina, 1996), 310-380.

${ }_{9}^{9}$ Directly, in the cases in which non-legislative rulemaking is adopted directly on the basis of the founding norms (the EU Treaties).

${ }^{10}$ M. McCubbins et al. (n 7 supra), at 255.

11 ibid, at 254.

12 J. J. G. Canotilho, 'Procedimento Administrativo e Defesa do Ambiente', (1991) Revista de Legislação e Jurisprudência, a.123, n.3798, 261-270, at 264 .

13 A. von Bogdandy (n 5 supra), at 11, 21-22.

14 This formulation of the problem goes back to an article in German by: F. Werner, 'Verwaltungsrecht als Konkretisiertes Verfassungsrecht', (1959) Deutsches Verwaltungsblatt, 527-533.
} 
executive actors and executive tasks at the level of the EU political system. One of the ways it makes the EU executive function more visible is by means of delegated and implementing legislation as laid down in Articles 290 and 291 TFEU. $^{15}$

Secondly, it mainstreams very prominently general principles on the democratic legitimacy of the Union which extends beyond the Union representative institutions (the European Parliament and the Council) to include a more participatory understanding of democracy. The Lisbon Treaty for the first time links openness, transparency and participation at treaty level with democracy within the framework of "democratic principles". Article 11 explictly embraces a participatory understanding of democracy, complementary to representative democracy (Article 10 TEU). Such a complementary approach appears necessary since executive rulemaking is one step removed from rule making by representatives in parliament due to delegation of rule-making powers to the executive. Our argument therefore is that supplementary forms of democracy may be particularly useful in infusing democracy in the respective procedures.

Thirdly, by reference to the principles of transparency, openness and participation in Articles 10 and 11 TEU as well as to the principles of good administration in Article 41 of the Charter of Fundamental Rights, the Lisbon Treaty explicitly lays down general principles that frame, or should frame the EU administration. These are accompanied by the legislator's duty ("shall" in Article 298(2) TFEU) to establish provisions that implement such principles. The principles on democracy and on the EU administration overlap insofar as openness is concerned. Together, the principles on participatory democracy, transparency, openness and good administration define some of the essential normative yardsticks against which the legitimacy and lawfulness of executive rulemaking procedures ought to be assessed. Whether there should be any specific structured and potentially codified overall proceduralisation of executive rule-making, is also a question of concretising the constitutional principles and values of the Union.

By means of introduction to the specific articles in this special edition we focus on two principles that, in the view of the innovative concept of democracy the Treaties enshrine, ${ }^{16}$ are core to the EU political system and, hence, in the view defended in this article, to its administration and the respective procedures: transparency and participation. We add a third principle - the principle of care. The principle of care is a principle specific to the administrative procedure. It requires public bodies to undertake 'full and impartial assessment of all relevant facts' prior to decision-making. ${ }^{17}$ We argue

\footnotetext{
$15 \mathrm{~J}$. Ziller, 'Separation of Powers in the European Union's Intertwined System of Government. A Treaty Based Analysis for the Use of Political Scientists and Constitutional Lawyers, (2008) LXXIII Il politico 133, at 138, 147-152; K. Lenaerts and M. Desomer, 'Towards a Hierarchy of Legal Acts in the European Union? Simplification of Legal Instruments and Procedures', (2005) 11 European Law Journal 744, at 750.

${ }^{16}$ A. von Bogdandy, 'The European Lesson for International Democracy: The Significance of Articles 9-12 EU Treaty for International Organizations', (2012) 23 European Law Journal 315.

17 See e.g. Case C-310/04 Spain v Council [2006] ECR I-7285, paras 123, 130: '[a] proper study of the effects of that reform on the profitability of cotton production requires an examination of the consequences the reform is liable to produce for ginning undertaking situated in the production regions.' See also: Case T-24/90 Automec v Commission [1992] ECR II-2223, para 79. The CJEU now has established case law reviewing the legality of a measure under the principle of proportionality by establishing whether there is proof of the respect of the duty of care: Case C-176/09
} 
that the notions of 'full' and 'impartial' assessment of 'all relevant facts' have a participatory dimension, insofar as they require the inclusion of diverse views arising from the general public and all parties which identify themselves as having an interest in a regulatory matter.

We highlight the gap between the normative implications of these principles and the current legislative and judicial rules. Our aim is to explore the meaning of the relevant Treaty rules as normative yardsticks of proceduralisation.

\section{Access to documents as a meta-norm for EU rule-makers}

\section{A. The province of transparency: from administration to constitution}

In the literature openness and transparency are often used interchangeably and without a great deal of conceptual precision. ${ }^{18} \mathrm{It}$ is possible however to conceptualise transparency as one component of openness and participation as the other. ${ }^{19}$ Transparency can be defined as the ability to observe decision-making and rule-making processes whereas participation refers to the opportunity to participate in these decision-making and rulemaking processes. Transparency can include access to documents only, ${ }^{20}$ the actual availability of documents, ${ }^{21}$ or even information in a more general sense that reveals the thinking behind a decision or the way in which a decision is made. ${ }^{22}$ But openness is the broader concept that is defined for our purposes as the extent to which citizens can monitor and influence legislative and executive processes through access to information and access to decision-making arenas. ${ }^{23}$

Prior to the Treaty of Amsterdam, transparency-related measures were viewed as a matter for the affected institutions themselves, to do with their internal functioning and hence falling under their respective rules of procedure. This essentially self-regulatory approach meant that initially the tendency was to view the principle of public access to documents as at most a voluntarily assumed specific principle of administrative law that has gradually, through the medium of case law, acquired some procedural flesh and substance. ${ }^{24}$ The focus in these early years was on gradually constructing a right of access

\footnotetext{
Luxembourg v EP and Council [2011] ECR I-nyr of 12 May 2011, para 65 ; Case C-58/08 Vodafone and Others [2010] ECR I-nyr of 8 June 2010, para 55.

18 See for example, M. O’Neill, 'The Rights of Access to Community-held Documentation as a General Principle of EC law', (1998) 4 European Public Law 403; P. Settembri,'Transparency and the EU Legislator: 'Let he Who is Without Sin Cast the First Stone', ' (2005) 43 Journal of Common Market Studies 637.

${ }^{19}$ See further, A. Meijer et al., 'Open Government: Connecting Vision and Voice', International Review of the Administrative Science, special issue, 78 (1), March 2012, 10 - 29.

${ }^{20}$ See further, U. Öberg, 'Public Access to Documents After the Entry into Force of the Amsterdam Treaty: Much Ado About Nothing?', (1998) 2 European Union online papers.

${ }^{21}$ See for example, G. Brandsma, D. Curtin and A. Meijer, 'How Transparent are EU 'Comitology' Committees in Practice?', (2008)14 European Law Journal 819.

22 See, D. Stasavage, 'Open-door or Closed-door? Transparency in Domestic and International Bargaining' , (2004) 58 International Organization 667.

${ }^{23}$ See further, A.Meijer et al. (note 19 supra). The following draws on D. Curtin and J. Mendes, "Transparence et Participation: des Principes Démocratiques pour l'Administration de l'Union Européenne" Revue Française d'Administration Publique, 2011/1 (no 137-138), 101.

${ }^{24}$ On this case law see further, D. Curtin, 'Citizens' Fundamental Right of Access to Information: an Evolving Digital Passepartout?’, (2002) 37 Common Market Law Review 7.
} 
by the public to certain categories of document held by the three decision-making institutions (Commission, Council and the European Parliament). The General Court and the Court of Justice effectively built a body of case law that on the whole kept pressure on the institutions to behave fairly and to devise adequate systems of scrutiny. They tended in the early case law to interpret the scope of the legal provisions (decisions by the institutions based on their internal rules of procedure) rather broadly so that, for example, specific institutional arrangements did not operate to reduce the reach of the access to documents provisions. ${ }^{25}$ The technique of legal interpretation used by the Courts during this foundational period involved a type of teleological reasoning which placed the initial Code of Conduct adopted by two decision-making institutions in the context of its broader democratic purpose. ${ }^{26}$ The Courts tended to emphasize the underlying purpose of access to documents as resting on general notions of public control of the activities of public institutions. Thus, the Courts developed what can be termed a constitutional perspective on access to documents provisions avant la lettre. Only later were these 'rights' given an explicitly constitutional foundation, first in the Treaty of Amsterdam, then in the Charter on Fundamental Rights and later in the Lisbon Treaty (Article 15 TFEU).

This specifically 'legal' approach culminated with the adoption of a new and binding legal instrument, Regulation 1049/2001 that entered into force on 3 December 2001. ${ }^{27}$ Although, in accordance with then Article 255 EC, EU level legislation granted a public right of access to the documents of only the three main law-making institutions (the Commission, the Council of Ministers and the European Parliament), the access to documents legislation was applied voluntarily by a wide variety of other institutions and (quasi-) autonomous actors. ${ }^{28}$ The Treaty of Lisbon in Article 15(3), TFEU consolidates this position in practice with the explicit treaty level provision of the right of access to documents of the "Union institutions, bodies, offices and agencies, whatever their medium', very much in line with the previous Article 42 of the Charter on Fundamental Rights of the European Union.

The legal-constitutional approach is relatively solidly anchored in legal texts, including, as we have seen, at the most fundamental level of the Treaty on European Union in its Lisbon version. The provisions on public access to documents clearly have caused changes by giving citizens a tool to obtain the documents they wish to obtain, albeit with

\footnotetext{
${ }^{25}$ See further, for example, Case T-194/94, Carvel and Guardian Newspapers v Council [1995] ECR II-2765 and Case T-174/95, Svenska Journalistfo'rbundet (Swedish Union of Journalists) v Council [1998] ECR II-2289.

${ }^{26}$ See further, D. Curtin, 'Betwixt and Between: Democracy and Transparency in the Governance of the EU', in J. Winter, D. Curtin, A. Kellerman, B. de Witte (eds), Reforming the Treaty on European Union (Kluwer Law International, 1996), at 95.

27 See, Regulation (EC) 1049/2001 regarding public access to European Parliament, Council and Commission documents, OJ 2001, at 43. See further, European Commission, 'Green paper: public access to documents held by the institutions of the European Community. A Review', COM (2007) 185 final (18 May 2007). See too, Commission staff working document, report on the outcome of the public consultation on the review of Regulation (EC) 1049/2001 regarding public access to European Parliament, Council and Commission documents, SEC (2008) 29/2 (16 January 2008).

28 See further, J. Helikoski and P. Leino, 'Darkness at the Break of Noon: the Case Law on Regulation No. 1049/2001 on Access to Documents', (2006) 43 Common Market Law Review 735.
} 
a considerable and significant time lag. ${ }^{29}$ Access to documents has acquired the status of a rather fundamental norm in the EU legal and constitutional system. At the same time it has however also in recent years become highly 'legalized' with many of the most crucial issues as to the meaning of the exceptions, the relationship with national legal provisions and the relationship with other legal rights that also enjoy a fundamental status (e.g. privacy and data protection). The Court(s) in Luxembourg who were once seen as the 'unsung hero' of those seeking to open up the inner institutional workings of the EU have come under fire at times for what is perceived to be an unnecessarily generous interpretation of the scope and meaning of several key exceptions to the legal right. ${ }^{30}$ The courts are both restrictive and generous at more or less the same time with little predictability as to how they will interpret the scope of the exceptions. In addition there is some attempt to turn back the clock by the Commission in particular in the ongoing revision of the access to documents regulation. ${ }^{31}$

The Court's approach is underpinned by the complementary work of the Ombudsman. ${ }^{32}$ As arbiter of maladministration, the Ombudsman has an interest in transparency as good governance and the Code of good administrative behaviour helps to promote transparency through the formulation of policies as rules and guidelines. ${ }^{33}$ Indeed, the work of the Ombudsman helps to move the understanding of transparency in the EU context away from an individual and passive focus on the legal right of every citizen to have access to certain documents to a much broader and pro-active duty of the EU executive to ensure that information about its policies and actions are made genuinely accessible. The EO's inquisitorial procedures, allow him to access administrative files and also to make files public during the proceedings and are perhaps the most potent machinery for opening windows on public information yet devised. Thus the constitutionally guaranteed right of access to the Ombudsman acts as an important catalyst for openness and transparency. ${ }^{34}$

Overall, it is difficult to assess the effect of these practices in the specific realm of the EU executive rule-makers, as distinguished from the EU legislator. However, in recent years the Commission in particular has set up several different specific document registers including such instruments as the 'Register on Expert Groups', ${ }^{35}$ as well as the Commission's register of interest representatives. ${ }^{36}$ These include a very detailed

\footnotetext{
${ }^{29}$ See further, L. Cotino, 'Theory and Reality of Public Access to EU Information', in

D. Curtin, A. Kellermann and S. Blockmans (eds), The EU Constitution: the Best Way Forward? (Kluwer, 2005), at 233.

${ }^{30}$ See further, J. Helliskoski and P. Leino (n 28 supra).

31 See further, F. Maini, J. Villeneuve and M. Pasquier, 'Less is More'? The Commision Proposal on Access to EU

Documents and the Proper Limits of Transparency', Revue Francaise d'Administration Publique, 2011/1 (no 137-138), 155170.

32 For an overview of the activities of the Ombudsman in this respect see, I. Harden, 'The European Ombudsman's Efforts to Increase Openness in the Union', in V. Deckmyn (ed), Increasing transparency in the European Union (European Institute of Public Administration, 2002), at 123, in particular at 130 et seq.

33 European Ombudsman, European Code of Good Administrative Behaviour, available in the latest version at $<$ http://www.euro-ombudsman.eu.int/_>.

${ }^{34}$ See too, C. Harlow, 'Transparency in the European Union: Weighing the Public and Private Interest', in J. Wouters, L. Verhey and P. Kiiver (eds), European Constitutionalism Beyond Lisbon (Intersentia, 2009), at 209.

${ }_{35}$ See, <http://ec.europa.eu/transparency/regexpert/index.cfm>.




'comitology' register ${ }^{37}$ and other specific web sites by the various Directorate Generals as well as a specific register on expert groups. All of these specific registers and web sites relate more generally to the province of the administration in a general sense and may include some documents of a more internal nature (for example minutes of committee meetings, meeting documents and minutes of meetings as well as draft decisions). They are particularly relevant to understand decision-making processes supporting the enactment of implementing - administrative - rulemaking.

\section{$B$ The normative gaps}

Transparency should ideally enable the public to reconstruct a rule-making process and also ultimately be in a better position to hold the rule makers to account for their decisions or failings. The mere existence of a passive right of access to documents is merely a very initial perspective from which it is possible to see a hazy and distant vista of democratic principles applicable to the EU executive as a whole. To bring this vista more into focus requires both an active attitude and practice of access to information by the administration itself as well as the active input in one way or another of both interested stakeholders and the wider public, depending on the subject matter and remit of the rule making and administration in question.

Viewed from this perspective EU practices of transparency often do not comply with these standards. Considerable reliance has been placed on the legal road by those seeking to draw back further the veil of secrecy that hangs over decision-making at the EU level. This has provided relatively solid albeit limited guarantees of transparency, in particular given the powers of review of the Courts and of the Ombudsman. However, although these efforts, and the practices of the EU institutions, have clearly provided the public with more information on EU rule-making than before, it does not necessarily provide it with all the tools to reconstruct a decision-making process, in particular in the administrative realm. The increased transparency of the comitology committees is a case in point. Although there is now neatly organized information available on comitology committees that is accessible on-line, it is still impossible to fully understand discussions in a meeting given its limited and often superficial nature.38

These caveats notwithstanding, it is undeniable that transparency allows for an "administrative style more open and transparent, and, as such, more adequate to the democratic principle and the rule of law". ${ }^{39}$ In this sense, transparency is not to be understood as an additional, autonomous source of legitimacy. Arguably, this is also not

EU (The Alliance for Lobbying Transparency and Ethics Regulation), Commission Lobby Register Fails Transparency Test,

eu.org/en/system/files/publications/Commission+Register+Fails+Transparency+Test.pdf>.

${ }^{37}$ See, $<$ http://ec.europa.eu/transparency/regcomitology/faq_en.htm>.

${ }^{38}$ G. Brandsma, D. Curtin and A. Meijer, 'How Transparent are EU 'Comitology' Committees in Practice?', (2008) 14 European Law Journal 819.

39 E. Schmidt-Aßmann, 'La Legitimación de la Administración Como Concepto Jurídico', (1993) Documentación Administrativa 163, at 211. 
the way it is framed in the Lisbon Treaty. ${ }^{40}$ Transparency (and participation) are rather factors improving the democratic quality of decisions. ${ }^{41}$ Transparency is an essential condition to effective participation but at the same time both transparency and participation together are necessary to constitute a genuinely open administration. A political system will only be 'open' in a democratic perspective if it engages citizens to participate actively in the decision-making processes, whether as a basis for opinion formation for e.g. voting or for staying in touch with decision-makers. For the latter purpose, the mere availability of documents (information) on its own is not sufficient ${ }^{42}$.

Precisely because, there is more to democracy in the EU administration than the mere existence of transparency practices, law is likely to have a significant contribution to make in adjusting current procedures to match some of the normative standards required by an ideal of democracy. The role of law in solidifying transparency in the EU political system is indicative of its potential contribution to tackle the democratic shortcomings of institutional practices. Law does not however provide a panacea for the problems that have arisen in practice. To conclude, the current rules and practices of transparency can support a vista of democratic principles for the EU executive, but the institutional practices on which Article 11 TEU relies display significant limitations in view of its purported democratic ideals.

\section{Participation as a meta-norm for EU rule-makers}

\section{A The province of participation}

Participation has manifold meanings and can serve a variety of different functions: it can be a means of voicing and defending affected rights and legally interests, of improving efficiency of regulatory processes and policy outputs), and it can be a source of democratic input into decision-making. In EU law, in the form of the right to be heard, it is one of the general principles of law, established as such in the case law of the Courts and enshrined in sector legislation. ${ }^{43}$ In institutional practice, participation has been a characteristic of EU policy-making decision-making since the beginning of integration, which acquired renewed relevance as a 'principle of good governance' in the follow up of the White Paper on Governance. ${ }^{44}$ In this sense, participation has been a constitutive

\footnotetext{
40 This is supported by the interplay between Article 10 and Article 11 of the TEU, and in particular by Article 10(1). See too B. Kohler-Koch, 'Zivilgesellschaftliche Partizipation: Zugewinn an Demokratie Oder Pluralisierung der Europaischen Lobby?, in B. Kohler-Koch and C. Quittkat, Die Entzuberung Partizipativer Demokratie, Zur Rolle der Zivilgesellschaft bei der Demokratisierung von EU Governance (Campus Verlag, 2010).

${ }^{41}$ E. Schmidt-Aßmann (n 39 supra), at 212.

42 See, T. Hueller, 'Assessing EU strategies for publicity', (2007) 14 Journal of European Public Policy 563; and D. Naurin, Deliberation Behind Closed Doors: Transparency and Lobbying in the European Union (ECPR Press, 2007). 43 See, among many others, Case 17/74, Transocean Marine Paint Association v Commission [1974] ECR 1063; Case 234/84, Belgium v Commission [1986] ECR 2263, para 27; Case C-135/92, Fiskano v Commission [1994] ECR I-2885, para 39; Case T-260/94, Air Inter v Commission [1997] ECR II-997, para 60. See also Article 41, para 2, sub a of the Charter of Fundamental Rights. See, further, E. Barbier de la Serre, 'Procedural Justice in the European Community Case-law Concerning the Rights of the Defence: Essentialist and Instrumental Trends', (2006) 12 European Public Law 225.

44 Commission Communication 'An open and structured dialogue between the Commission and special interest groups' (Communication 93/C63/02, of 12 of Dec. 1992, SEC/92/2272 final) available at <http://www.ec.europa.eu/civil_society/interest_groups/index_en.htm>). European Governance. A White Paper',
} 
feature of the EU polity long before the Lisbon Treaty gave it the status of a democratic principle. Yet, one may argue that Article 11 TEU can hardly be seen merely as a continuity of previous institutional practices. Rather, it brings about a normative shift regarding the role of participation in the EU. ${ }^{45}$

The provisions of Article 11 TEU are, to some extent, open-ended. However, Article 11 also defines normative standards binding on the institutions. ${ }^{46}$ This ambivalence is well expressed in Article 11(1) TEU. It explicitly gives leeway to choose the appropriate means to make the participation of citizens and representative associations effective; at the same time, it defines that there needs to be a 'public exchange of views', 'in all areas of Union action.' In addition, in one reading of Article 11 TEU, there are normative implications following from participation as a principle of democracy. This provision, read in conjunction with Articles 9 and 10(3) TEU, grounds a principle of democratic citizen participation that requires focusing on the citizen and on its relationships with the Union. ${ }^{47}$ Rulemaking procedures that intend to concretise participation as a principle of democracy need to ensure equality - both in access and in treatment - and transparency. Both are conditions upon which the democratic value of participation depends. ${ }^{48}$ Forms of participation that fall short of minimum democratic guarantees should be interpreted as having a different purpose (e.g. ensuring responsiveness of regulation). They may have a valuable instrumental function in the policy process, but they cannot be understood as enhancing the democratic legitimacy of decisions of the Union.

Where does executive rulemaking stand when seen in the light of Article 11 TEU? Executive rulemaking does not have the democratic legitimacy of legislative procedures, but has a relevant impact both on legislative choices, via the executive activity that precedes legislative acts (e.g. opinions and legislative proposals), and on the concretization of those legislative choices, via delegation and implementation (in a broad sense). It is, at the same time, the level of public action of the Union where procedural standards of participation have been to a great extent overlooked by the Commission, by the Court of Justice and by the Parliament.

\section{B Participation and executive rulemaking: The normative gaps}

\section{The Commission's consultation standards}

When in 2002 the Commission published its Communication on principles and minimum standards of consultation, significantly, one of the policy choices was to exclude from its scope of application non-legislative initiatives not covered by impact assessment procedures. ${ }^{49}$ Following an emerging 'case-by-case' practice of conducting

COM (2001) 428 final, Brussels, 25.7.2001; See further, J. Mendes, Participation in European Union Rulemaking: A RightsBased Approach (Oxford University Press, 2011), Chapter 3, Sections 3.1 and 3.2.

45 J. Mendes, 'Participation and the Rule of Law After Lisbon: A Legal View on Article 11 TEU', (2011) 48 Common Market Law Review 1854. Generally, on the significance of Articles 9-12 TEU, see von Bogdandy (n 16 supra), 318-319.

46 P. Craig, The Lisbon Treaty (Oxford University Press, 2011). J. Mendes (n 45 supra), at 1868.

${ }^{47} \mathrm{~J}$. Mendes (n 45 supra), at 1862.

48 ibid. This claim is buttressed by the Draft recommendation of the European Ombudsman in his inquiry into complaint 2558/2009/(TN)DK against the European Commission, which stresses equality and transparency as pillars of participatory democracy (pt. 9).

49 Communication from the Commission: Towards a reinforced culture of consultation and dialogue- General principles and minimum standards for consultation of interested parties by the Commission (COM(2002)704), 11 December 2002, at 15. 
impact assessments on certain non-legislative measures, the 2009 Impact Assessment Guidelines confirmed the widening of the scope of impact assessment procedures to 'certain implementing measures (so called 'comitology' items) which are likely to have significant impacts, ${ }^{50}$ The respective consultations are subject to the 2002 standards. This still excludes the application of consultation standards from a large share of executive rulemaking - all those not subject to impact assessment procedures. ${ }^{51}$ Even where consultation procedures are conducted at this level of regulation, and depending on the Commission's assessment of their 'significant impact, ${ }^{52}$ many are not bound by the selfimposed rules of the Commission. This is problematic, both from a political and legal point of view. ${ }^{53}$ Consultation standards are one of the main instruments directed at guaranteeing inclusiveness, transparency and accountability of participation. These values have, at least, a 'democratic echo' and are generally excluded from participation in nonlegislative rulemaking. If the Commission intends to use its 2002 consultation standards to give effect to Article $11 \mathrm{TEU}$, their scope would need to be revised possibly beyond what the Commission currently envisages. ${ }^{54}$ But also the content of the Commission's principles and standards may need to be revised in light of Article 11 TEU. Their shortcomings, when assessed against the standards of Article 11, have been forcefully highlighted by the Ombudsman in a case of maladministration pertaining to the publication of consultation documents only in one official language. ${ }^{55}$

\section{The interpretative role of the Court}

The Court of Justice has refrained from imposing participation rights or duties of consultation in rulemaking procedures whenever these are not explicitly specified either in a Treaty or in a legislative provision. The leading judgment in this matter remains Atlanta. ${ }^{56}$ While the arguments the Court invoked therein related to 'a Community legislative process, ${ }^{57}$ the Court did not hesitate to deny participation rights also with regard to non-legislative procedures when at stake were acts of general scope. ${ }^{58}$ In 1996 ,

50 Commission, 'Impact Assessment Guidelines', 15 Jan. 2009, SEC(2009) 92, at 6 (available at <http://ec.europa.eu/governance/impact/commission_guidelines/docs/iag_2009_en.pdf>), emphasis added.

51 The 2009 Guidelines preceded the entry into force of the Lisbon Treaty and, hence, the creation of the category of delegated acts. However, at first sight, there are no reasons to support a literal interpretation of the guidelines, according to which these acts would be a priori excluded from impact assessment procedure. An example confirms this: by legislative determination, the Commission needs to assess the impact of delegated acts adopted on the basis of Directive 2010/30/EU of 19 May 2010 on the indication by labelling and standard product information of the consumption of energy and other resources by energy-related products, O.J. L 153/1; Art. 10(3)(b)). See further Alemmano, Meweuse in this issue.

$52 \mathrm{On}$ the lack of transparency of the Commission's selection of initiatives that undergo impact assessments, see European Court of Auditors, 'Impact Assessments in the EU institutions: do they support decision making?', Special Report No. 3/2010, at 28 and 46.

53 See, however, Alemanno and Meuwese in this issue.

54 Commission Communication, 'Smart Regulation in the European Union', COM(2010)543 final, Brussels, 8.10.2010, at 3. See also J. Mendes (n 45 supra), 1869-1870.

55 Draft recommendation of the European Ombudsman concerning his inquiry into complaint 640/2011/AN against the European Commission (24 November 2011).

56 Case T-521/93, Atlanta and others v Council and Commission [1996] ECR II-1707, para 70 to 74; Case C-104/97 P, Atlanta and others v Commission and Council [1999] ECR I-6983, para 35 to 38.

57 Case C-104/97 P, Atlanta and others v Commission and Council [1999] ECR I-6983, para 70.

58 Case T-122/96, Federazione Nazionale del Commercio Oleario (Federolio) v Commission [1997] ECR II-1559, para 75; Case T-199/96, Laboratoires pharmaceutiques Bergaderm SA and Jean-Jacques Goupil v Commission [1998] ECR II-2805, para 50 and 58; Case T-13/99, Pfizer Animal Health SA v Council [2002] ECR II-3305 para 487 and Case T70/99, Alpharma Inc. v Council [2002] ECR II-3495, para 388. See Türk in this issue and, further, J. Mendes (n 44 supra), 193-229. 
when the first Atlanta judgment was given, issues of democracy - in particular, of sources of democracy alternative to representation - were already a salient topic in the political agenda. The Court apparently chose not to enter this debate. Instead, it endorsed a strict legal view on the democratic foundations of the then European Community, as exclusively based on representative democracy and on the participation of Economic and Social Committee in rulemaking.

The same stance is considerably more conditioned now, in view of Article 11 TEU. ${ }^{59}$ The recognition or otherwise of participation rights, or of legally enforceable rules of participation, may require a distinction between the realm of political participation and that of participation grounded in legal reasons, as Türk defends in this issue. Arguably, the Courts should abstain from imposing participation rights in policymaking procedures or requirements of public-interest participation, where no overriding legal principle would require it. Drawing the line between these two worlds, also in the realm of executive rulemaking, defining when there is a shift from the political to the legal, is no easy task. ${ }^{60}$ However, it might be one the Court will be faced with in view of the looser requirements of standing of Article 263(4) TFEU.

\section{Legislative procedural rules}

Hitherto, the EU legislator has not been active in enshrining procedural standards of participation in non-legislative procedures, in contrast with its position regarding the decision-making procedures followed by the Member States when implementing EU law. ${ }^{61}$ Article 11 TEU may determine a change in this respect. Arguably the task of concretising the normative standards of Article $11 \mathrm{TEU}$ in instances of non-legislative rulemaking ought to be primarily in the hands of the legislator. Law may not the only means of giving effect to Article 11 TEU. $^{62}$ Yet, the choice of when and how participation is appropriate in given regulatory processes, in order to give effect to Article 11 TEU, is a fundamental political choice and one which the legislator is best placed to make, given its democratic legitimacy (Article 10(2) TEU). Ultimately, such choice will define the degree of participatory democracy imprinted to EU rulemaking procedures in concretisation of the Treaties, in particular, in view of the complementarity Articles 10 and 11 TEU establish. Whether via a general act - possibly based on Article 298(2) TFEU - or via sector legislation, the legislator ought to make explicit the choices on how to concretise the democratic provisions of the Treaty with regard to non-legislative procedures, given their potential impact on legislative choices. Although the Parliament and the Council are dependent on the Commission's initiative, it is fully within their scope either to make use of Articles 225 and 241 TFEU (to trigger a legislative initiative) or to introduce amendments to the Commission's proposals in this regard.

\footnotetext{
${ }^{59}$ See J. Mendes (n 45 supra), 1873-1875.

${ }^{60}$ P. Craig, EU Administrative Law (Oxford University Press, 2012), 294-298 and the different proposals of Türk, in this issue [at 5 and 6 ] and J. Mendes (n 44 supra), 355-362.

${ }^{61}$ P. Craig (n 60 supra), 298-299.

62 P. Craig, The Lisbon Treaty (Oxford University Press, 2011); J. Mendes (n 45 supra).
} 


\section{Procedural Principles Supporting Participatory Democracy}

It arises from much of the discussion above on administrative procedural law as concretization of constitutional principles, especially when thought of in the context of a system of both representative and participatory democracy, that a key component of administrative procedure law necessary to realize these constitutional principles is related to gathering, use and distribution of information. In the same vein, participation has certain procedural pre-conditions that need to be fulfilled to be exercised. Many of the procedural principles ensuring the functions of participatory democracy and information are linked to notions of good administration and with it to the overarching umbrella principle of the rule of law.

In this respect, one of the central innovations of the case law of the Court of Justice with respect to the definition of overarching principles also applicable to rule making has been the distillation from the umbrella principle of the rule of law, what is often called the 'duty of care'. ${ }^{63}$ In a different formulation, also used by the Court, the principle of the duty of care requires public bodies to undertake 'full and impartial assessment of all relevant facts' prior to decision making. The 'duty of care' is therefore sometimes also referred to as the 'duty of diligent and impartial examination'. ${ }^{44}$ Being able, as an administration, to fully and impartially examine and assess relevant facts requires acquiring such information. The notions of 'full' and 'impartial' assessment of 'all relevant facts' could ground an obligation to enter into broad consultation and hearing. This is a normative argument that is not currently reflected in the case law of the Courts. Yet, arguably, a full investigation of all relevant facts would require giving the possibility to potentially interested parties to notify their views. Properly framed participatory procedures could also be able to contribute to the impartiality of the administration by providing a broad range of information to be taken into account. In this, the above mentioned transparency requirements for interest groups participating in such procedures might be a valuable tool to also protect the impartiality of the administration when engaging in executive rule making. Consultation and hearing are in that sense principles contributing to the realization of democratic participation by the citizens. However, for this purpose, full information about pending measures is necessary. In EU case law, not surprisingly, the duty of care is closely linked with the right to a fair hearing which carries with it the rights of access to the relevant information held by the public body. ${ }^{65}$ Finally, compliance with the duty of care needs to be demonstrated through reasoning of an act. Only a sufficiently reasoned decision will indicate compliance with

\footnotetext{
63 See, in particular, Cases T-211/02 Tieland Signal Ltd v Commission [2002] ECR II-3781, para 37; Case T-54/99 max.mobil v Commission [2002] ECR II-313, paras 48-51; Case C-449/98 P IECC v Commission [2001] ECR I-3875, para 45; Case T-24/90 Automec v Commission [1992] ECR II-2223, para 79; Case T-95/96 Gestevisión Telecinco v Commission [1998] ECR II-3407, para 53; Joined cases 142/84 and 156/84 BAT and Reynolds v Commission [1987] ECR 4487, para 20.

${ }^{64}$ See, in particular, Case C-269/90 Technische Universität München v Hauptzollamt München- Mitte [1991] ECR I-5469, para 14.

65 H-P. Nehl, Principles of Administrative Procedure in EC Law (Hart Publishing, 1999), 103-105. See on the principle of the equality of arms Case T-306/01 Ahmed Ali Yusuf [2005] ECR II-3533, para 72 with many further references in the case law.
} 
the duty of care and the standards of investigation. ${ }^{66}$ This reasoning enables expost review to discern which interests were taken into account to which degree and why, thereby potentially contributing to the impartiality of decision-making.

For these reasons, the duty of care is also now regarded as one of the general principles protected under the umbrella notion of 'good administration. ${ }^{.67}$ Good administration, initially developed exclusively in the case law of the Courts, has been cautiously and partially codified in Article 41 CFR. Article 41 CFR contains the notions of hearing, information and reasoning of a decision. The constitutional principles discussed in this context, thus establish framework-rules on how much information needs to be collected prior to decision making and of which quality. Given that the realization of constitutional norms in the EU context is not a value free undertaking, such collection of information cannot be based on certain parties to a procedure only. We would submit that in view of the principles of transparency and openness of the EU legal system discussed above, the duty of care must be interpreted also in a way which requires the inclusion of diverse views arising from the general public and all parties which identify themselves as having an interest in a regulatory matter.

The duty to investigate fully and impartially all aspects of a case prior to taking a decision can, for example, encompass the analysis of its potential impact on other collateral aspects. ${ }^{68}$ Courts have so far reviewed this mainly in the context of their review of the principle of proportionality. In a series of recent cases, the Courts have confirmed that an administration can demonstrate its compliance with its duty of care and argue the proportionality of its action when providing for reasoned impact assessment of a planned measure. This point was initially made by Advocate General Sharpston. ${ }^{69}$ The CJ now has established case law reviewing the legality of a measure under the principle of proportionality - i.e. the fact that no less onerous measures could have been employed to reach a policy goal - by establishing whether there is proof of the respect of the duty of care by means of an impact assessment report drafted prior to the entry into force of the of a measure. ${ }^{70}$

66 Joined Cases T-371 and 394/94 British Airways and others and British Midlands Airways v Commission [1998] ECR II-2405, para 95.

67 Also protected by Art. 41(1) CFR (Charter of Fundamental Rights of the European Union). C-248/99 P Monsanto [2002] ECR I-1, paras 91-93. However, the Court did not annul the Commission's contested act on that basis, since it concluded that the appellant had not established that the decision at issue was not actually, in that specific case, adopted in disregard of the principle of sound administration and the duty of care.

68 See e.g. the situation in Case C-310/04 Spain v Council [2006] ECR I-7285, paras 123, 130: '[a] proper study of the effects of that reform on the profitability of cotton production requires an examination of the consequences the reform is liable to produce for ginning undertaking situated in the production regions.'

69 Sharpston AG, in a matter concerning a Spanish support scheme for cotton producers, referred to the obligation of the institutions to explore the element of a decision fully, prior to taking a decision, as the obligation to undertake an 'impact study'. This obligation is linked to the principle of proportionality insofar as it imposes 'an obligation on Community institutions at least to satisfy themselves that the proposed measures are prima facie adequate to attain the legitimate aims pursued'. Opinion of Sharpston AG in Case C-310/04 Spain v Council [2006] ECR I-7285, para 80. The violation of the duty to care by the institutions was so severe that they were criticized as appearing arbitrary: 'In the absence of any impact study, certain choices made by the Commission and the Council appear arbitrary' (para 94).

70 Case C-176/09 Luxembourg v EP and Council [2011] ECR I-nyr of 12 May 2011, para 65 ; Case C-58/08 Vodafone and Others [2010] ECR I-nyr of 8 June 2010, para 55; Case C-343/09 Afton Chemical [2010] ECR I-nyr of 8 July 2010 , paras 29, 36, 57. In Afton, the court points out that this line of reasoning holds even though the impact assessment undertaken by the Commission was not binding on the Parliament or Council taking a legislative decision based on the Commission proposal. A similar reasoning might apply if the Commission has discretion to decide on the basis of an 
Given the EU's fast-paced constitutional developments, the gap between an explicit requirement of impact assessment and a clear statement that such assessment is incomplete without the possibility of participation should soon be closed. This can be done through the medium of case law of the Courts or by design: the creation of administrative procedures taking seriously the rights of individuals and the obligations of the executive branch of power in the EU.

\section{Constitutional Principles and Executive Rule-Making Procedures}

The discussion of the relevance of constitutional principles for structuring executive rule making procedures would remain rather abstract if it were not linked to a more in-depth understanding of rule making procedures. Executive rule making as the object of analysis, is, as we have discussed in the introduction to this article a dynamic matter. It is undertaken in the context of a rapidly evolving complexity of actors, both public and private, organized on the European level and in the Member States. ${ }^{71}$ Yet, some systematization of the field may grant, especially in view of the complexity of different policy fields and plurality of actors involved, a picture allowing a simplified but comprehensible model. Our aim is not to define how the above-mentioned principles ought to apply to executive rulemaking, but to spell out what executive rulemaking involves, thereby mapping the terrain where constitutional principles could be brought to effective concretisation.

Executive rule making typically involves overlapping-sometimes coincident, sometimes asynchronous-phases.72 A typical functional description of such cyclical elements within the process of executive rule making is a policy-cycle approach. Such would distinguish between, first, agenda setting; secondly, policy formulation; thirdly related decision-making and adoption of measures; fourthly implementation including monitoring and enforcement which may lead to re-evaluation of a policy and new agenda setting. Admittedly, such a cyclical model is a simplification of a complex reality yet it appears helpful to lay the basis for de-constructing the rule-making process into its archetypical elements. The procedures which might best reflect the realization of constitutional values therein may differ from one policy to another. They may also be provided for in policy-specific legislation, ${ }^{73}$ or is, as in many cases, only contained in internal rules by the Commission or a specific agency's management board. ${ }^{74}$ But procedural rules for rule making procedures will in one way or another need to address the standard elements of agenda setting, policy formulation and policy adoption at least.

agency proposal where the agency was in charge of undertaking the in-depth impact assessment of a proposed measure.

${ }^{71}$ H. Hofmann and A. Morini, 'The Pluralisation of EU Executive-Constitutional Aspects of "Agencification"”, (2012) European Law Review, 419-442.

72 H. Hofmann, G. Rowe and A. Türk, Administrative Law and Policy of the European Union (Oxford University Press, 2011), at 26.

${ }^{73}$ E.g. Art. 4, 5 of Regulation 881/2004 of the EP and Council on the establishment of a European Railway Agency (ERA).

74 E.g. EASA Management Board Decision 01-2012 amending and replacing Decision 08-2007 concerning the procedure to be applied by the agency for the issuing of opinions, certification specifications and guidance material (rulemaking procedure) of March 13, 2012. 
The policy-cycle concept also has the advantage that it allows describing administrative activity quite realistically as much more than a mere technical 'conveyor-belt-style' transposition of value choices undertaken on the legislative level.75 This in turn recalls the guiding relevance of basic constitutional principles for the structuring of procedures ('Ordnungsprinzipien des Verfahrensrechts'). ${ }^{76}$

\section{A. Agenda setting}

In legal terms, the activities associated with the phase of 'agenda setting' might be regarded as the definition of a regulatory topic, or an objective of executive rule making. It consists of identifying policy objectives and formulating a first set of policy goals to be pursued by an act of executive rule making. Agenda setting, in terms of procedural law also requires the identification of rights of initiative for a rule-making activity. This may differ from one policy area to another.

In terms of the realization of constitutional principles discussed above, the main issues regarding agenda setting are the questions of access to information about planned rule making activities as pre-condition for the possibility of input from various parties potentially interested in or affected by a planned measure.

The right of initiative for adopting a policy has in EU law traditionally been the prerogative of the Commission as recipient of delegation of executive powers. Generally, such delegating acts empower the Commission to initiate an executive rule making process on the basis of its own analysis or an 'outside' initiative. ${ }^{77}$ Agenda setting by the Commission is also influenced by Article 12 TEU obliging the Commission to react to a successful citizen's initiative on the proposal of 'legal acts of the Union'. A citizens' initiative therefore can result in either legislative proposal or a proposal to adopt a nonlegislative act of executive rule making.

Some policy-specific legislation, also introduces the right of agencies to initiate EU rulemaking. In fact, increasingly, policy-specific legislation has entrusted EU agencies or networks of national agencies coordinated on the European level with undertaking preparatory steps for rule-making. Agencies are free to react to individual's proposals of

\footnotetext{
${ }^{75}$ H. Hofmann, G. Rowe and A. Türk (n 72 supra), at 26.

${ }^{76}$ This is also a result from lacking legal basis for a common set of procedural rules prior to the entry into force of the Treaty of Lisbon which by including Article 298 TFEU has created a legal basis for some overarching rules and procedures. Only few aspects of administrative procedures have so far been regulated by EU law in a cross-policy fashion. These include comitology, executive agencies, the financial regulation as well as certain aspects of data protection (in the EU context) and access to data provisions, the EU language regime, staff matters as well as to a certain degree impact assessment rules.

${ }^{77}$ Examples are the implementation of obligations under agreements entered into by the EU under public international law such as the various agreements concluded in the context of the WTO hold ample examples for such obligations. EU policies (like those of the Member States) are often directly influenced by developments undertaken in contexts of public international law. Rule-making, to take some concrete examples, can be influenced by UN security council decisions on anti-terror measures. It can also be influenced by obligations arising from the WTO's TBT or SPS agreements, containing obligations of mutual recognition of foreign - non EU - regulatory approaches.
} 
doing so.78 An important part of the agenda setting phase is the obligation to develop and publish so called 'work programmes'. The Commission and agencies are subject to such obligations arising from policy specific legislation or legislation establishing agencies. The Commission is also bound by its own rules of procedure. Programming obligations, however, exist predominantly for future formal acts. Rule making procedures resulting in internal or non binding acts generally do not contain such obligations.

Key elements at the phase of agenda setting therefore appear to be openness and transparency. This may require not just 'passive' transparency but also 'active' provision of information on possible future executive rule making procedures. Such requirements of active transparency might also require distribution of information about how to propose rule-making initiatives. Difficulties exist in form of the diversity of executive actors and associated problems of 'systemic' transparency. It will often be difficult for non-experts to discern responsibilities.

\section{B. Policy Formulation}

The phase of agenda setting is often interwoven with, or followed by, the analysis and evaluation of policy alternatives by the institution or body drafting the rules. In terms of realizing the constitutional principles discussed in this article, the phase of policy formulation is the central moment for undertaking a full and impartial assessment of all relevant facts of a decision under the duty of care. Thereby it will be necessary to develop tools to ensure that all relevant information is present at the moment of decision making so that it can be assessed and interests, rights and values can be weighed in a rule making procedure. Such information gathering requirements by the executive actors has as mirror-principle, the rights of participation. This is the phase in which interested parties need to be able to make their position known in a meaningful and informed manner.

Tools for the proceduralisation of the phase of analysis and policy formulation exist in the EU. Some policy specific legislation establishes them. ${ }^{79}$ In other cases they are defined in internal administrative guidelines of the Commission or agencies. Occasionally, they are also defined in the legislative acts delegating powers. Often, procedural provisions devised for this require the analysis of draft rule-making concepts by forms of impact assessment procedures, sometimes as cost-benefit analysis with or without general notice and comment style procedures for public participation. The need for public participation in this phase has led to debates in the legal and political science

\footnotetext{
78 The recent establishment of the European Supervisory Authorities (ESA Directive 2010/78/EU) provides such powers in Articles 10 and 15 of the Regulations establishing the European Banking Authority (EBA, Regulation 1093/2010, [2010] OJ L331/12), the European Securities and Markets Authority (ESMA, Regulation 1095/2010, [2010] OJ L331/84) and the European Insurance and Occupational Pensions Authority (EIOPA, Regulation 1094/2010, [2010] OJ L331/48). The three supervisory authorities are called not only to adopt preparatory measures, but draft regulatory and implementing standards. These standards are preparatory measures to be adopted by the Commission under Article 290 and 291 TFEU.

${ }^{79}$ E.g. the obligation of the European Supervisory Authorities to undertake cost benefit analysis and consultation of stakeholders by the agencies.
} 
literature as to the necessity of an obligation for an impact-assessment inspired procedures prior to the publication of a regulatory act.80 Given that the underlying rationale for impact-assessment-inspired preparatory procedures is to increase quality and thereby legitimacy of rule-making, such benefits might arise in the context of a more thorough investigation of the relevant facts and regulatory alternatives of a regulatory project.

In any case, however, the details of such approaches require a definition of which impact-assessment inspired procedures for executive rule-making would precisely be required. They need to clarify inter alia whether they should be but one step of a preparatory procedure or whether they should cover all elements of the preparation of an act from sourcing of ideas, consultations, seeking scientific expertise to establishing a final reasoned draft regulatory act. In order for documentation of the full gathering and weighing of relevant information having taken place and in order to provide the political and judicial supervision mechanisms of executive actors, the final result of the preparation of a rule making procedure requires a reasoned report. This is part of the duty to provide reasons and finalizes the fact finding and information gathering phase.

\section{Adoption of a Rule}

These procedural steps generally lead to the Commission formulating a draft rule. This can either be adopted formally as a delegated or an implementing act under Articles 290 or 291 TFEU or it can be another form of adoption of executive rules through guidelines, planning documents and others. When agencies are involved in the preparation of executive rule-making, as they are in an increasing amount of policy areas, their proposals generally require final adoption by the Commission under Articles 290 and 291 TFEU. The Commission is, however, in many cases not entirely free to accept or dismiss an agency proposal. Especially in the most recently regulated policy area, the sector of banking and securities supervision, the Commission is subject to procedural restrictions. These include requirements to consult with the agency or face procedural sanctions such as being called before the EP to explain differences, 81 or face longer periods of supervision by EP and Council in cases of Article 290 TFEU.82

In the past, one of the main lines of debate about the democratic legitimacy of executive rule making was the question how the EP, as directly elected representative of the EU

\footnotetext{
${ }^{80}$ See e.g. A. Alemanno, 'A Meeting of Minds on Impact Assessment: When Ex Ante Evaluation Meets Ex Post Judicial Control', (2011) 17 European Public Law, 485-505.

${ }^{81}$ E.g. under Art 17(2) of the legal basis creating the European Air Safety Agency (EASA) (Regulation No 216/2008, [2008] OJ L79/1) or Arts. 10 and 15 of the Regulations establishing the European Banking Authority (EBA, Regulation 1093/2010, [2010] OJ L331/12), the European Securities and Markets Authority (ESMA, Regulation 1095/2010, [2010] OJ L331/84) and the European Insurance and Occupational Pensions Authority (EIOPA, Regulation 1094/2010, [2010] OJ L331/48).

82 E.g. Art.13(1) of the legal basis of the European Supervisory Authorities (ESA Directive 2010/78/EU) provides such powers in Articles 10 and 15 of the Regulations establishing the European Banking Authority (EBA, Regulation 1093/2010, [2010] OJ L331/12), the European Securities and Markets Authority (ESMA, Regulation 1095/2010, [2010] OJ L331/84) and the European Insurance and Occupational Pensions Authority (EIOPA, Regulation 1094/2010, [2010] OJ L331/48).
} 
citizens could influence the procedure. ${ }^{83}$ By contrast to the EP's rights to participation in acts of legislative nature (those based directly on Treaty provisions as legal basis) which were famously strengthened gradually since the SEA in 1986, the EP had a much more difficult time in establishing the notions of participation with regard to delegated rule making powers. The Commission had been made subject to supervision and advice from comitology committees by the Council since the early years of the Community. But the comitology decisions which were adopted in the wake of the entry into force of the SEA, the decisions of 1987 and 1999 as well as the amendment of 2006 only gave the EP marginal rights of supervision and information. The same holds true for the comitology regulation of 2011 which is based on the new Article 291 TFEU. By contrast, the EP has significantly gained powers regarding the supervision of Commission's adoptions of delegated acts when it received powers to adopt these under Article 290 TFEU.

But this article has argued that the realization of the fundamental principles of democracy go beyond the notion of parliamentary involvement into executive rule making. This poses interesting questions regarding the validity of previous direct involvement of interested parties. Since the final decision-making procedures are related to constitutionally mandated procedures, the notion of participation and direct involvement is balanced at this stage with those of representative democracy through the EP, the Council and Member State experts in the comitology committees. This balancing of direct representation and indirect representation reflects the two approaches formulated in Article 11 TEU.

In other cases, the result of a rule making procedure might be the publication of a plan (e.g. in the areas of environmental law, regional planning, infrastructures, state aids etc.) or a guideline which predominantly has internally binding force. Here, formal adoption procedures are rare. The relevance of the principles of transparency and openness, however, would require that these acts be published. Publication, under general principles of law such as the protection of legitimate expectations and equal treatment, may have in itself further legal consequences. These consequences, however, are the expression of the Union being a legal system governed by the rule of law and protecting individual rights.

\section{Beyond this special issue : a research agenda}

The argument made in this article requires further research on ways to infuse EU rulemaking with (specific) constitutional values (principles). It raises several questions that, at this stage, remain unanswered. Could the constitutionalisation of executive rule making procedure be part of a nascent EU administrative procedure law on rule-making? What should the understanding of the democracy principle as formulated primarily in

\footnotetext{
${ }^{83}$ See e.g. the discussion in A. Töller, H. Hofmann, 'Democracy and the Reform of Comitology', in: M. Andenas, A. Türk (eds), Delegated Legislation and the Role of Committees in the EU (Kluwer, 2000), 25-50 with further references.
} 
Articles 9-12 TEU be with regard to administrative justice? What would the implications be with regard to executive rulemaking? Would a general EU law on administrative procedures which would include rule making procedures be capable of contributing to the 'constitutionalisation' of administrative law? What could be done to strengthen the principles of participatory democracy, transparency and openness? Which risks to efficient rulemaking do they effectively entail? What should the differences, if any, be for the establishment of directly binding versus only indirectly binding ('soft') acts be in terms of proceduralisation?

This special issue only establishes the very first building blocks of the constitutional understanding of executive rulemaking procedures. The contributions to this special issue cannot of course cover the entire spectrum of questions raised. They nevertheless in our view constitute important building blocks for our future research agenda and shed illuminating light on a number of important underlying issues. In particular, what they collectively reveal is that, despite the diversity and differences amongst policy areas of the preparatory steps leading to executive rule-making, some basic elements of rulemaking procedures seem to be reappearing in various policy areas.

Joana Mendes discusses the contents of Articles 290 and 291 TFEU in the light of the principles of participation and transparency. She argues that the debate on the proceduralization of delegated and implementing acts cannot be reduced to an internal dimension where the relative powers of the institutions and the Member States are defined. The contribution by Thomas Christiansen and Mathias Dobbels is relevant in this context discussing to a greater degree the current developments and fault-lines of inter-institutional dispute regarding these supervisory tools and the intricacies of supervision. Linda Senden looks at the 'dark matter' of executive rule making beyond the formal provisions of the Treaties- the field often referred to as soft law, despite the fact that what is called soft might have some very sharp edges in reality. She in particular looks at the emerging practice of post legislative guidelines from the perspective of transparency and participation. Alberto Alemanno and Anne Meuwese discuss a different aspect of the progressive proceduralization of executive rulemaking: the use of impact assessment in delegated rulemaking. They analyse how the tool of impact assessment has standardized elements that - if well employed - could be at the service of the realization of openness and control over the exercise of delegated rulemaking.

Details of the various steps of agency activity in the field of executive rule making are analysed in depth in the contribution of Edoardo Chiti. Chiti shows in his contribution that despite the lack of a common procedural framework almost all agencies active in the adoption of executive rules follow procedures that include participation and have a normative concern for transparency. At the same time, agencies tend to resort to soft law, which is under-proceduralised in both respects. The contribution of Madalina Busuioc explores specifically the case study of the European financial supervisory authorities as probably the most far-reaching case of agency involvement in executive rule-making procedures. Alexander Türk's paper finally focuses on the important issue of judicial review. He explains the (rather limited) contribution the Court makes to setting 
procedural and substantive standards for EU administrative rulemaking; the liberalisation of the standing rules in the Treaty of Lisbon will expose this gap even more. 